\title{
Słuchanie literatury w społeczeństwie medialnym
}

Andrzej Hejmej

TEKSTY DRUGIE 2021, NR 2, S. 301-319

DOI: 10.18318/td.2021.2.18 | ORCID: 0000-0002-3385-0664

1.

Kakofonia medialna stała się jedną z charakterystycznych cech komunikacji kulturowej we współczesnym świecie', stanowi istotny i coraz bardziej ekspansywny element otaczającego wszystkich pejzażu dźwiękowego. Jej oddziaływanie w dzisiejszej zglobalizowanej kulturze zachodniej trudno byłoby precyzyjnie oszacować, chociaż zarazem dobrze wiadomo, że człowiek z narastającą intensywnością doświadcza przemocy w sferze audialnej, że jest uwikłany w proces formowania, by tak określić, nowoczesnego ucha (mam tutaj na uwadze skutki słyszenia/słuchania „innym uchem"2, problem, do którego odnosił się już w latach 6o. ubiegłego wieku Pierre Schaeffer). Jako homo consumens,

1 Istnienie zjawiska „kakofonii medialnej”|Jürgen E. Müller sygnalizował w drugiej połowie lat 8o. (J.E. Müller Texte et médialité - une introduction, w: Texte et médialité, éd. J.E. Müller, Lehrstuhl Romanistik I, Universität Mannheim, Mannheim 1987, s. 9).

2 P. Schaeffer Akuzmatyka, przeł. J. Kutyła, w: Kultura dźwięku. Teksty o muzyce nowoczesnej, red. Ch. Cox, D. Warner, słowo/obraz terytoria, Gdańsk 2010, s. 112. Zob. P. Schaeffer L'Acousmatique, w: tegożTraité des objets musicaux. Essai interdisciplines [1966], Éditions du Seuil, Paris 1977, s. 98.
Andrzej Hejmej prof. dr hab., zatrudniony w Katedrze Teorii Literatury Wydziału Polonistyki UJ. Członek PSKL i AlLC/ ICLA. Przewodniczący Komitetu Redakcyjnego serii „Projekty Komparatystyki". Ostatnio opublikował: Komparatystyka. Studia literackie - studia kulturowe (2013), Musicality of a Literary Work (2018), Comparative Literature. Literary Studies - Cultural Studies (2018). Kontakt: a.hejmej@uj.edu.pl 
homo irretitus itd. funkcjonuje on w warunkach coraz bardziej zanieczyszczanej i sztucznie rozszerzanej nowoczesnej audiosfery - nie tyle z racji świadomego wyboru, ile przede wszystkim z konieczności, za sprawą między innymi rozwoju technologii i środków masowego komunikowania. Słyszenie i słuchanie w dobie nowoczesności, w czasach pojawienia się nowych dźwięków, spektakularnej „ewolucji w kierunku dźwięku-hałasu”3 i niespotykanego na taką skalę w historii ludzkości tempa modyfikacji środowiska dźwiękowego, są z pewnością konsekwencją złożonych przemian kulturowych związanych ze szczególną intensywnością doświadczeń audialnych, niemniej warto przy tym zwrócić uwagę, że w znacznym stopniu przyczyniają się do tego rozmaite praktyki a ku z m a t y c z n e, czyli praktyki słuchania pośredniego. Inaczej mówiąc, zmiany w zakresie percepcji słuchowej zachodzące w społeczeństwie medialnym - a sugestywnie dopowiadając: w erze głośników - to rezultat reakcji człowieka na dotkliwy w obecnej rzeczywistości nadmiar dźwięków nie tylko bezpośrednich, ale i zmediatyzowanych. Stan ten rodzi swoiście rozumianą nadwrażliwość na dźwięk czy, jeśli ująć problem najogólniej, hiperestezję (zgodnie z etymologią łac. hyperaesthesia).

Kwestia nowoczesnego słyszenia/słuchania rozstrzygana jest na wiele sposobów ${ }^{4}$, chociaż wspólnym elementem nawet z gruntu zupełnie różnych i nieprzystających do siebie koncepcji okazuje się ekspansywność dźwięku. Peter Szendy na przykład - w sytuacji objaśniania specyfiki percepcji słuchowej w dzisiejszym świecie i przyjęcia optyki umożliwiającej w polu interdyscyplinarnej refleksji wyjście poza wymiar czysto estetyczny - nie bez powodu mówi o nieuchronnym procesie "intensyfikacji słuchania” (une intensification de l'écoute), wzmagającej się „hi per e stezji słu chowej” (l'hyperesthésie auditive) ${ }^{6}$. Nie bez powodu też reakcję człowieka na nową akustykę autor Sur écoute.Esthétique del'espionnage (zarazem autor innego opracowania książkowego

3 L. Russolo Sztuka hałasów. Manifest futurystyczny, przeł. M. Matuszkiewicz, w: Kultura dźwięku. Teksty o muzyce nowoczesnej, s. 33. Zob. L. Russolo L'Arte dei rumori, Edizioni Futuriste di "Poesia", Milano 1916, s. 10-11.

4 Pokazują to dobitnie badania z zakresu sound studies prezentowane np. w tomie The Sound Studies reader (ed. J. Sterne, Routledge, London-New York 2012).

P. Szendy Sur écoute. Esthétique de l'espionnage, Minuit, Paris 2007, s. 26.

6 Tamże, s. 26.

7 E. Thompson The new acoustics, 1900-1933, w: tejże The soundscape of modernity: architectural acoustics and the culture of listening in America, 1900-1933, MIT Press, Cambridge, MA-London 2002, S. 59-113. 
poświęconego słuchaniu - Écoute, une histoire de nos oreilles ${ }^{8}$ ) rozpatruje metaforycznie w świetle zjawiska dobrze znanego w branży telefonii, które określa

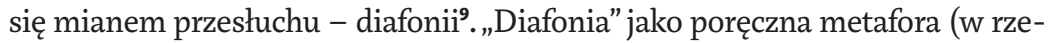
czywistości zachowująca podstawowe znaczenie słowa odnoszącego się do zakłóceń przekazu dźwiękowego, interferencji fal dźwiękowych utrudniających prowadzenie rozmowy telefonicznej) wiąże się w tym kontekście ze słyszeniem jednocześnie wielu nakładających się na siebie, a zatem kakofonicznych, niepożądanych dźwięków.W szerszym ujęciu problemowym jest rzeczą oczywistą, że nowy status słyszenia w kulturze audiowizualnej, efekt permanentnego bycia $w$ dźwięku - niezależnie od tego, jak zostaje zdefiniowane interesujące nas zagadnienie, czy jako problem „diafonii”, czy jako problem kakofonii medialnej bądź kakofonii pejzażu dźwiękowego, czy teżjako problem „,nowoczesnej słyszalności"10 - prowadzi także do modyfikacji praktyk słuchania i, w konsekwencji, samego rozumienia słuchania"1.

\section{2.}

W sytuacji uwzględnienia długofalowych zmian zachodzących w obrębie nowoczesnej audiosfery nietrudno zwrócić uwagę na symptomatyczne zjawisko istniejące w rozmaitych przestrzeniach społeczeństwa medialnego - tzw. $\mathrm{d}$ źwi ię $\mathrm{k}$ ł a, towarzyszący przekaz audialny. W tym kontekście warto od razu przypomnieć, że wzorem dla tego typu działania, o czym aktualnie często się zapomina, pozostają eksperymenty muzyczne określane mianem muzyki tła. Pierwsze próby nieabsorbującej muzyki w XX wieku - zyskujące nazwę „musique d'ameublement"12 - zawdzięczamy kompozytorowi francuskiemu

8 P. Szendy Écoute, une histoire de nos oreilles, Éditions de Minuit, Paris 2001.

9 Nawiązuję w tym miejscu do rozdziału zatytułowanego Surécoute et diaphonie (P. Szendy Sur écoute. Esthétique de l'espionnage, s. 26-31).

10 Zob. V. Erlmann Reason and resonance: a history of modern aurality, MIT Press, New York-Cambridge, MA 2010.

11 Kwestia ta rozstrzygana jest dzisiaj z wielu perspektyw i, co oczywiste, interesuje również muzykologów, o czym świadczy najlepiej opracowanie Lawrence'a Kramera The hum of the world: a philosophy of listening (University of California Press, Oakland, CA 2019).

12 Użyte przez Satiego określenie "musique d’ameublement" zostało sugestywnie objaśnione przez kompozytora m.in. w liście do Jeana Cocteau pisanym najprawdopodobniej 1 marca 1920 roku (Erik Satie: Correspondance presque complète, réunie, établie et présentée par O. Volta, Fayard, Paris 2000, s. 396-397). 
Erikowi Satie, a mianowicie takim jego kompozycjom, jak Carrelage phonique czy Tapisserie en fer forgéz 1917 roku oraz takim jego eksperymentom, jak oryginalna propozycja "niesłuchania” muzyki wybrzmiewającej w antrakcie sztuki Maxa Jacoba Ruffian toujours, truand jamais ${ }^{13}$, sztuki, która została wystawiona 8 marca 1920 roku w paryskiej Galerie Barbazanges. Eksperyment Satiego sprzed stu lat, o czym świadczy między innymi kapitalny komentarz Dariusa Milhauda w Notes sansmusique $^{14}$, nie był udany, ponieważ - wbrew założeniom i jednoznacznym instrukcjom kompozytora (zgodnie z rozpowszechnioną pogłoską miał on w trakcie zaskakujących dla wszystkich uczestników sekwencji wydarzeń, w chwili ogólnej konsternacji publiczności, wygłosić przewrotne słowa: „Mais parlez donc! Circulez! N'écoutez pas!"15) - sprowokował odbiorców do uważnego słuchania zaaranżowanych na nowo fragmentów Mignon Ambroise'a Thomasa i Danse macabre Camille'a Saint-Saënsa.W świetle tego czasowo odległego już dla nas wydarzenia, jednej z wielu prowokacji artystycznych z początków ubiegłego wieku, można by stwierdzić paradoksalnie, że pomysł Satiego po upływie dekad zyskuje idealną wręcz realizację nie w przestrzeniach koncertowych czy teatralnych, lecz w realiach społeczeństwa medialnego - za sprawą technologicznie rozszerzanej (preparowanej) audiosfery i wszechobecnej kakofonii medialnej kształtujących nowe warunki słyszenia/słuchania.

Działanie dźwięku tła w aktualnej rzeczywistości kulturowej (ze względu na charakterystyczny nadmiar bodźców rodzące w jakiejś mierze efekty analogiczne do działania obrazu) należałoby rozpatrywać jako wyjątkowo skuteczny kanał komunikacji społecznej. Powód takiego twierdzenia jest oczywisty, zwłaszcza jeśli towarzyszy temu świadomość, że dźwięki otaczające człowieka w społeczeństwie medialnym i osadzające go w danej przestrzeni prywatnej lub publicznej - owe audialne formy gościnności i zarazem przemocy, swoiście rozumianej „wrogościnności”16 - są zwykle starannie

13 Trzyaktowa sztuka Jacoba (manuskrypt znajduje się w Bibliothèque Nationale de France, Collection Gompel-Netter), wystawiona w Galerie Barbazanges w dwóch częściach, ukazała się drukiem dopiero w 2019 roku: M. Jacob Ruffian toujours, truand jamais, éd. J.-C. Penchenat, P. Sustrac, "Les Cahiers Max Jacob” 2019 nr 19/20, s. 327-355.

14 Zob. D. Milhaud Notes sans musique, René Julliard, Paris 1949, s. 128. Zob. komentarz: O. Volta, w: E. Satie Écrits, Éditions Champ Libre, Paris 1977, przyp. 370, s. 307-308. Zob także P. Bertin Erik Satie et le Groupe des Six, "Les Annales” 1951 nr 4, s. 58. łączenia dwóch form: „hospitalité" (gościnność) i „hostilité” (wrogość). J. Derrida De l'hospitalité, Calmann-Lévy, Paris 1997, s. 45. 
zaplanowane, nakierowane na konkretną grupę odbiorców (tzw. przekaz ukierunkowany), pozostawiające trwały ślad w pamięci. Preparowana audiosfera w konsekwencji nierzadko prowokuje nieuświadomione i często pozornie tylko spontaniczne - wszak aranżowane zgodnie z wymogami konsumpcjonizmu, potrzebami politycznymi czy ideologicznymi - zachowania, najczęściej obliczone na mimowolne reakcje odbiorcy. Batalia toczy się na wielu frontach, z przyjęciem jednak podobnych reguł. Dobrze wiadomo, że osoby czy instytucje zaangażowane w produkcję dźwięku tła i odpowiadające za jego skuteczność dokładają wszelkich starań, aby ukryć rzeczywiste intencje związane z sytuacją osaczenia dźwiękiem. Podejmują one próby stworzenia i rozpowszechnienia takiego przekazu audialnego (audiowizualnego, polisensorycznego), w przypadku którego towarzyszące dźwięki (a szerzej: dźwięki, obrazy, zapachy) będą odbierane w określonej przestrzeni jako zupełnie „naturalne”. W tym wypadku zatem głównym i najbardziej pożądanym efektem działań jest, by tak to nazwać, a b s or bow a ni e ni e a b s o rbują cy m dźw i ęki e m (w celu np. osłabienia krytycznego myślenia czy to potencjalnego klienta sieci handlowej, czy to potencjalnego wyborcy; wywołania wrażenia przebywania „w klimatycznym miejscu" jak w sytuacji klienta pubu bądź w wyjątkowej i ekskluzywnej atmosferze jak w sytuacji bywalca kawiarni z tradycjami; utwierdzenia w poczuciu przynależności do takiej lub innej wspólnoty, chociażby słuchaczy danej rozgłośni radiowej bądź widzów danej stacji telewizyjnej itd.).

Odwołując się właśnie do tego typu praktyki, która, jak widać, może służyć w rzeczywistości różnym celom, chciałbym zatrzymać się przy pewnym istotnym szczególe. W społeczeństwie medialnym - w kulturze akuzmatycznej - mechanizm absorbowania nieabsorbującym dźwiękiem jest wykorzystywany już nie tylko w zamkniętych i łatwych do kontrolowania przestrzeniach (mam na uwadze wydarzenia kulturalne o charakterze i kameralnym, i masowym), w miejscach niepowtarzalnych z racji swego profilu, takich jak muzea (znakomitym przykładem są wypełniające poszczególne segmenty muzealne wiedeńskiego Haus der Musik dźwięki Beethovena czy Mahlera, których funkcja wydaje się analogiczna do funkcji muzyki zaproponowanej przez Satiego 8 marca 1920 roku w antrakcie sztuki Maxa Jacoba) i nie tylko w tzw. nie-miejscach ${ }^{17}$, jak dworce kolejowe czy lotniska, gdzie anonimowo

17 M. Augé Nie-miejsca. Wprowadzenie do antropologii hipernowoczesności, przeł. R. Chymkowski, Wydawnictwo Naukowe PWN, Warszawa 2010. Zob. M. Augé Non-lieux. Introduction à une anthropologie de la surmodernité, Le Seuil, Paris 1992. 
przemieszczający się w tłumie ludzie eksponowani są na dźwięki dobiegające z głośników, nakładające się na rozmaite przygodne głosy, szumy, hałasy. Otóż ten mechanizm absorbowania nieabsorbującym dźwiękiem zaczyna funkcjonować w tego rodzaju społeczeństwie - ze względu, by powtórzyć, na rozwój technologii i ekspansję mediów - na szeroką skalę (w sensie czasowym i przestrzennym). W konsekwencji pogłębiająca się kakofonia medialna w znacznym stopniu odpowiada za coraz bardziej zanieczyszczaną audiosferę i sposób bycia w dźwięku spowodowany wykorzystywaniem starych mediów, takich jak radio czy telewizja, mediów cyfrowych i interaktywnych, powszechnym używaniem urządzeń przenośnych (audialnych i multimedialnych), pozwalającym tworzyć indywidualnie sprofilowane mikropejzaże dźwiękowe.

Hiperestezja słuchowa, stanowiąca bez wątpienia jedną z charakterystycznych cech społeczeństwa medialnego, okazuje się dla wielu zjawiskiem pożądanym, sposobnością, by nowoczesne formy słyszenia/słuchania „innym uchem" traktować jako skuteczny kanał komunikacji społecznej. W takich okolicznościach trudno się więc dziwić, że wysiłki różnych instytucji zainteresowanych szczególną podatnością współczesnego człowieka na dźwięk są intensyfikowane i że próbuje się osiągnąć - ze względu na możliwości, jakie daje przekaz audialny - maksymalne zyski w wymiarze, co zrozumiałe, nie tylko ekonomicznym, lecz także społecznym, kulturowym, ideologicznym. Trudno też nie zauważyć, że przemilcza się jednocześnie negatywne skutki bycia w rozszerzonej audiosferze, chociażby te dobrze znane i precyzyjnie opisywane z medycznego punktu widzenia: problemy ze słuchem, coraz częstsze statystycznie występowanie niedosłuchu, proces stopniowego głuchnięcia obserwowany w obrębie danych grup wiekowych i poszczególnych populacji. Tym ważnym skądinąd aspektem nie zajmuję się tutaj, ale z zupełnie innych i oczywistych powodów - interesować mnie będzie bowiem przenikalność dźwięku w realiach społeczeństwa medialnego i reakcja człowieka na świat dźwięków umożliwiająca nowe spojrzenie na fenomen literatury.

\section{3.}

Jakakolwiek próba ujęcia zagadnienia identyfikowanego umownie w tytule jako „słuchanie literatury w społeczeństwie medialnym” powinna uwzględnić, jak sądzę, kwestię zmian w zakresie nowoczesnego słyszenia/słuchania, zasygnalizowane powyżej uwarunkowania i komplikacje. Należałoby przy tym dodać, że już w punkcie wyjścia zasadnicze trudności związane 
z percepcją słuchową stwarzają z jednej strony now o c ze s na a u d i o s fe r a (nowoczesny pejzaż dźwiękowy), z drugiej - zarazem - indywidualne percypowanie dźwięku, solipsystyczne słyszenie/słuchanie ${ }^{\mathbf{1 8}}$, uzależnione zawsze od sytuacji słuchającego, jego wrażliwości, predyspozycji, kompetencji, uważności itd. Nadmiar dźwięków wypełniających daną przestrzeń i otaczających człowieka w życiu codziennym - wpływ, jak to sugestywnie oddaje się w języku psychologii, ciągłego przebodźcowania - prowadzi niewątpliwie do rozmaitych czy nawet biegunowych reakcji: osłabienia uwagi i stanu obojętności, braku skupienia, słuchania mimochodem czy "podsłuchiwania”19 (słowo to oznacza w tym miejscu słuchanie bez niezbędnego zaangażowania) lub - wręcz przeciwnie - pobudzenia, nerwowości, rozdrażnienia, „schizofonii”20 (rozumianej, zgodnie z wykładnią Raymonda Murraya Schafera, jako swoiste „odczucie aberracji”21).

Mając świadomość kolejnych nawarstwiających się problemów, chciałbym ograniczyć argumentację do dwóch tylko kwestii. Pierwsza z nich łączy się z nowoczesnym doświadczeniem audialnym, z reakcją na dźwięk (w tym głos ludzki) czy - precyzyjniej rzecz ujmując - na świat dźwięków w społeczeństwie medialnym. Tenże świat dźwięków pojmowany jest przeze mnie jako całość zjawisk dźwiękowych organizujących audiosferę określonej rzeczywistości kulturowej, a zatem i jako czynnik wpływający również na kształt literatury oraz jej funkcjonowanie w społeczeństwie zdominowanym przez media (interferujące przekazy audialne i audiowizualne, analogowe i cyfrowe). Druga kwestia - w konsekwencji - łączy się z proponowanym

18 Por. np. S. Voegelin Sonic possible worlds: hearing the continuum of sound, Bloomsbury, LondonNew York 2014, s. 1, 70, 80, 155.

19 Notabene inne jest znaczenie tego słowa jako neologizmu u Szendy'ego (surécoute), który dostrzega z zaskakującą pomysłowością analogię czy, jak stwierdza, „powinowactwo strukturalne" między słuchaniem a szpiegowaniem (écoute - espionnage). Zob. P. Szendy Sur écoute. Esthétique de l'espionnage, s. 18.

R.M. Schafer Muzyka środowiska, przeł. D. Gwizdalanka, „Res Facta” 1982 nr 9, s. 300 (zob. także R.M. Schafer Muzyka środowiska, przeł. D. Gwizdalanka, w: Kultura dźwięku. Teksty o muzyce nowoczesnej, s. 57 i n.). Zob.: R.M. Schafer The tuning of the world, Alfred A. Knopf, New York 1977, S. 273; tegoż The music of the environment, Universal Edition, Vienna 1973 (również w: Audio culture: readings in modern music, ed. by Ch. Cox, D. Warner, Continuum, New York 2004, S. 2939; schizophonia, s. 34-35); tegoż The new soundscape: a handbook for the modern music teacher, Associated Music Publishers, New York 1969.

21 R.M. Schafer Muzyka środowiska, przeł. D. Gwizdalanka [1982], s. 301. Zob. R.M. Schafer The tuning of the world, s. 91. 
podejściem do literatury, mianowicie rozpatrywaniem utworów literackich, jak to określam, w kategoriach skryp toraln o ś ci (jako pisma i głosu), także z perspektywą badań komparatystycznych i badań literaturoznawczych kształtowanych pod wpływem rozmaitych koncepcji studiów nad dźwiękiem.

4.

Wyjdźmy od kwestii najogólniejszej. Na podstawie dzisiejszych praktyk lektury i sposobów interpretacji, legitymizujących zarówno indywidualne ujęcia i różne nurty badań literackich, jak i zarazem całe literaturoznawstwo jako samodzielną dyscyplinę naukową, można by nazbyt pospiesznie zakładać, że słyszenie i słuchanie oraz literatura nowoczesna, jeśli pominąć przypadki poezji dźwiękowej bądź niektóre realizacje e-literatury ${ }^{22}$, przynależą do zupełnie odmiennych sfer problemowych. W obrębie literaturoznawstwa monomedialnego, jak się wydaje przy pobieżnej ocenie, nie ma żadnego dającego się sensownie uzasadnić - przejścia od słyszenia (m.in. sytuacji doświadczania absorbującego, uciążliwego czy wręcz obezwładniającego hałasu) oraz słuchania (praktyk świadomego oddawania się sztuce dźwięków i światu dźwięków) do sposobów odbioru a fo n i c z n i e z reguły rozumianej rzeczywistości tekstu, które od kilkunastu stuleci zawdzięcza się przecież percepcji wzrokowej ${ }^{23}$. W bliższym rozpoznaniu problem ten jednak okazuje się bardziej skomplikowany: w obecnych realiach kulturowych trudno byłoby jednocześnie nie zauważyć, że literatura to nie tylko fenomen tekstu i pisma, co odnotowywał już w latach 6o. ubiegłego wieku komparatysta amerykański Harry Levin ${ }^{24}$ (we wstępie do książki Alberta B. Lorda The Singer of Tales), że w przestrzeń literacką niejednokrotnie wprowadza dzisiejszego odbiorcę głos autora, deklamatora czy performera (nierzadko zresztą - w trybie

Zob.: E. Winiecka Poszerzanie pola literackiego. Studia o literackości w internecie, Universitas, Kraków 2020; B. Bodzioch-Bryła Sploty:przepływy, architek(s)tury, hybrydy. Polska e-poezja w dobie procesualności i konwergencji, Wydawnictwo Naukowe Akademii Ignatianum w Krakowie i Wydawnictwo WAM, Kraków 2019.

23 Jak wiadomo, praktyki cichej lektury ukształtowały się w kulturze europejskiej stosunkowo późno, około XIV wieku. Bezcenna jest np. reakcja św. Augustyna na zachowanie biskupa Ambrożego z Mediolanu - jego sposób cichego czytania. Zob. Święty Augustyn Wyznania, 6.3, przeł. Z. Kubiak, PAX, Warszawa 1987, s. 110-111.

24 H. Levin Przedmowa, w: A.B. Lord Pieśniarz i jego opowieść, przeł. P. Majewski, Wydawnictwa UW, Warszawa 2010, s. 49. Zob. H. Levin Preface, w: A.B. Lord The singer of tales, Harvard University Press, Cambridge, MA 1960, s. xiii. 
zapośredniczenia za sprawą technologii i rozmaitych mediów - głos akuzmatyczny), że do lektury takiego czy innego tekstu przystępuje się, chcąc nie chcąc, z określonym doświadczeniem audialnym i w warunkach konkretnego środowiska dźwiękowego. Aby zasygnalizować w tym kontekście jedynie skalę komplikacji z samym definiowaniem w najnowszym literaturoznawstwie fenomenu literatury, wystarczy ograniczyć się do wskazania kilku przykładów „nieklasyfikowalnych” realizacji literackich, jak chociażby utworów Mirona Białoszewskiego ściśle związanych z sytuacją słyszenia/słuchania (a także z praktyką nagrań magnetofonowych ${ }^{25}$ pochłaniającą twórcę Teatru Osobnego), cyklu poetyckiego Stanisława Barańczaka Podróż zimowa, funkcjonującego zgodnie z intencją autora jako „wiersze do muzyki Franza Schuberta"26 (a zarazem unikatowych poetyckich „przekładów” librett operowych pomieszczonych w tomie Stanisław Barańczak stucha arcydziek27), zapisów Marcina Świetlickiego czy Andrzeja Sosnowskiego zyskujących autorskie realizacje sceniczne ${ }^{28}$, opowiadania Antoniego Libery Toccata $C$-dur istniejącego $\mathrm{w}$ formie tradycyjnego tekstu i w formie słuchowiska radiowego ${ }^{29}$, powieści Inni ludzie $e^{30}$ Doroty Masłowskiej jako przykładu narracji zanurzonej w kulturze hip-hopu (muzyce rapu), narracji funkcjonującej z sugestywnym komentarzem czy podpowiedzią interpretacyjną w postaci hip-hopowego trailera ${ }^{31}$.

Kwestionowanie tego stanu rzeczy lub też unikanie w badaniach literackich refleksji w związku z coraz bardziej problematycznym statusem literatury (problematycznym zwłaszcza w sytuacji uwzględnienia jej bogatej

Białoszewski do słuchu (6 CD), Bôłt Records, 2014.

S. Barańczak Podróż zimowa. Wiersze do muzyki Franza Schuberta, Wydawnictwo a5, Poznań 1994 .

Zob. Stanisław Barańczak słucha arcydzieł, wyboru dokonał R. Krynicki, Wydawnictwo a5, Kraków 2016.

Praktyka tego rodzaju jest charakterystyczna dla Marcina Świetlickiego od samego początku jego twórczości, począwszy od programu telewizyjnego Nieprzysiadalność, zrealizowanego dla TVP 2 (Kraków 1993) i płyty O.gród K.oncentracyjny (Music Corner Records, MCRDo10, 1995).

29 A. Libera Toccata C-dur, w: tegoż Niech się panu darzy. I dwie inne nowele, Biblioteka "Więzi", Warszawa 2013, s. 68-127. Radiowa adaptacja (emisja 30 września 2017 roku w Programie II Polskiego Radia, w cyklu „Teatr Polskiego Radia”) w reżyserii Antoniego Libery, w wykonaniu Andrzeja Mastalerza (z muzyką Roberta Schumanna; Tomasz Marut - fortepian).

D. Masłowska Inni ludzie, Wydawnictwo Literackie, Kraków 2018.

Trailer książki Inni ludzie znajduje się na stronie: https://www.youtube.com/watch?v=G8KGWvoS7zg (7.07.2020). 
historii i długiej drogi wiodącej od realiów oralności pierwotnej do realiów oralności wtórnej, cyfrowej itd.) mija się z jakimkolwiek celem. Podobnie jak przyznawanie wyjątkowego statusu tylko wybranym realizacjom literackim, które daje się uznać wedle arbitralnych kryteriów za bezsporne manifestacje doświadczenia audialnego ${ }^{32}$. Połowicznym skądinąd i siłą rzeczy nie do końca zadowalającym, jak sądzę, rozwiązaniem jest zarazem wyodrębnianie określonych zjawisk - niektórzy badacze skłonni są bowiem zaakceptować próby interpretacji literatury nowoczesnej w kontekście audiosfery, słyszenia i słuchania, ale wyłącznie na ustalonych przez siebie prawach, jak dzieje się w przypadku mówienia na przykład o „audiotekście”33 (Charles Bernstein) czy "literaturze audialnej”34 (Maryla Hopfinger). Doceniając niewątpliwe walory i wartość tego rodzaju propozycji ${ }^{35}$, wychodzę mimo wszystko z założenia, że literaturę nowoczesną - w kontekście zjawisk audialnych społeczeństwa medialnego - należałoby en bloc rozpatrywać w kategoriach skryptoralności, to znaczy w kategoriach naraz pisma i głosu (dźwięku). Uwzględnienie i eksponowanie właśnie wymiaru audialnego, szeroko pojmowanej sfery nowoczesnej audialności oraz procesów i praktyk słyszenia/słuchania staje się tutaj podstawą argumentacji, posunięciem, które decyduje o charakterze proponowanego ujęcia literatury. Jest przy tym rzeczą oczywistą, że dla rozumienia w takiej optyce realizacji literackich (nie tylko zresztą zaliczanych do literatury nowoczesnej) zasadniczy okazuje się fenomen głosu ludzkiego.

\section{5.}

Potrzebę włączenia w obręb refleksji literaturoznawczej różnorodnych literackich i nieliterackich zjawisk oralnych, które zrodziła nowoczesność, jak

Takie "ekskluzywistyczne" podejście kwestionuję także w innym miejscu, w związku z objaśnianiem fenomenu słyszenia poprzez język. Zob. A. Hejmej Słyszeć poprzez język. Pogłosy awangardy, "Zagadnienia Rodzajów Literackich" 2019 z. 2, s. 23.

Zob. Ch. Bernstein Introduction, w: Close listening: poetry and the performed word, ed. by Ch. Bernstein, Oxford University Press, New York-Oxford 1998, s. 12-13. dadaistycznego poświęcony takim zjawiskom, jak "wiersz bruitystyczny" czy "wiersz symultaneistyczny" (Manifest dadaistyczny (1918), przeł. Z. Klimowiczowa, w: Artyści o sztuce. Od van Gogha do Picassa, wybór i oprac. E. Grabska, H. Morawska, PWN, Warszawa 1969, s. 320; zob. Dadaistisches Manifest, w: Dada Almanach, Hrsg. R. Huelsenbeck, Erich Reiss Verlag, Berlin 1920, S. 39). 
i wypracowywania i porządkowania sposobów ich analizy oraz prób konceptualizacji w perspektywie audialnej akcentuje się w zasadzie od początku XX wieku ${ }^{36}$. Dopiero jednak w realiach społeczeństwa medialnego, gdy literatura przestaje być wyłącznie kwestią pisma i zyskuje narzucający się wymiar audialny (audiowizualny), widać znakomicie, że zagadnienie oralności wymaga na nowo gruntownego przemyślenia. Potwierdzają to skądinąd najnowsze badania, w których łatwo zaobserwować wyraźnie zarysowującą się tendencję: otóż oprócz omawiania niegdysiejszych form określających tryb funkcjonowania człowieka już w fazie społeczeństw pierwotnych, w „świecie oralno-audialnym" ${ }^{\text {37 }}$, czyli oralności „pierwotnej” bądź „elementarnej"38, analizuje się usilnie także formy ukształtowane i wciąż kształtowane w aktualnej rzeczywistości

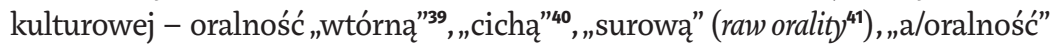
$\left(\right.$ a/oralit $\left.{ }^{42}\right)$, ,zmediatyzowaną"43, ,trzeciorzędną"44, ,cyfrową"45 etc. Podejmowa-

36 Notabene jedną z pierwszych propozycji jest ważna publikacja Milmana Parry'ego L'Epithète traditionnelle dans Homère: Essai sur un problème de style homérique, Société d'Éditions "Les Belles Lettres", Paris 1928.

37 W.J. Ong Oralność i piśmienność. Słowo poddane technologii, przeł. J. Japola, Wydawnictwa UW, Warszawa 2011, s. 125.Zob. W.J. Ong Orality and literacy: the technologizing of the word, Methuen, London-New York 1982, s. 74.

Taka formuła pojawia się w polskim przekładzie książki Christiana Vandendorpe’a Od papirusu do hipertekstu. Esej o przemianach tekstu i lektury (przeł. A. Sawisz, Wydawnictwa UW, Warszawa 2008, s. 28).

39 W.J. Ong Oralność i piśmienność. Słowo poddane technologii, passim. Zob. W.J. Ong Orality and literacy: the technologizing of the word.

O. Soffer "Silent orality": toward a conceptualization of the digital oral features in CMC and SMS texts, "Communication Theory" 2010 vol. 20 no. 4, s. 387-404.

41 B. LaBelle Raw orality: sound poetry and live bodies, w: Voice: vocal aesthetics in digital arts and media, ed. by N. Neumark, R. Gibson, Th. van Leeuwen, MIT Press, Cambridge, MA 2010, s. 147-173. Ch. Bernstein Introduction, w: Close listening: poetry and the performed word, s. 13.

44 Jest to propozycja Erica Crumpa sformułowana w związku z oralno-piśmiennym charakterem rozmowy w trybie online. Zob. Deafness and orality: an electronic conversation, "Oral Tradition" 1993 vol. 8 no. 2, s. 413.Zob. także J. December Characteristics of oral culture in discourse on the net, Paper presentation at the Penn State Conference on Rhetoric and Composition, University, Park, Pennsylvania, July 8, 1993, https://www.december.com/john/papers/pscrc93.txt (7.07.2020). features in CMC and SMS texts, s. 388). 
ne wielotorowo wysiłki odnotowywania i definiowania kolejnych przejawów oralności to z pewnością nie tyle skutek uwodzenia inwencją terminologiczną i wyrafinowaną retoryką wywodu, ile zwłaszcza rezultat mierzenia się z konkretnymi zjawiskami oralnymi występującymi w globalizującym się społeczeństwie medialnym. Inaczej mówiąc, jest to wyraz świadomości zmian zachodzących - w wyniku rozwoju nowoczesnych technologii i sieci mediów - w sferze środowiska dźwiękowego, a zatem i wyraz świadomości kształtowania się nowych warunków egzystencji inter-esse.

Ze względu na koncepcję skryptoralności interesować nas powinna w sposób szczególny kwestia o r a l n o ś c i (z) m e d i a t y z o w a n ej, kwestia dwóch równie ważnych znaczeń tej formuły, która pozwala zaakcentować - po pierwsze - zawłas zczen i e (określa oralność przejętą przez media, wchłoniętą przez system mediów; innymi słowy, uwikłanie głosu autora w transfer medialny), po drugie - zapośredniczenie (odnosi się w przypadku interpretatora do doświadczenia akuzmatycznego, skutku procesu mediatyzacji kultury). Jeśli ma się na uwadze zasygnalizowany wyżej tygiel propozycji łączących się poza jednym wyjątkiem - oralnością pierwotną - z mechanizmem oralności (z)mediatyzowanej, nietrudno dojść do wniosku, że znajdujemy się już dzisiaj w zupełnie innej sytuacji kulturowej niż jeszcze na przełomie lat 80. i 9o. XX wieku (w takim przekonaniu utwierdza chociażby lektura zapisów dobrze znanego literaturoznawcom badacza zjawisk oralności Paula Zumthora, który w tamtym właśnie okresie nie tylko formułował wnikliwe diagnozy w często komentowanej książce $L a$ lettre et la voix. De la "littérature" médiévale ${ }^{46}$, lecz także pracował nad oryginalnym w założeniach tekstem noszącym tytuł Oralite $\left.{ }^{47}\right)$. WXXI stuleciu, w czasach rozwoju mediów cyfrowych i rozpoczynającej się - za sprawą nowych technologii i cyfryzacji życia - czwartej rewolucji przemysłowej ${ }^{48}$, w erze internetu ludzi i internetu rzeczy, dochodzi do spektakularnego nasilenia komunikacji kulturowej za pośrednictwem rozszerzanej czy preparowanej

46 We wstępnych fragmentach książki, jak wiadomo, Zumthor rozróżnia trzy typy oralności (pierwotną, mieszaną [oralité „mixte”] oraz wtórną). Zob. P. Zumthor Perspectives, w: tegoż La lettre et la voix. De la "littérature" médiévale, Éditions du Seuil, Paris 1987, s. 18-19.

47 Zob. P. Zumthor Oralité. Zob. komentarz: Ph. Despoix Document: "Oralité" - un inédit de Paul Zumthor, "Intermédialités" 2008 no. 12, s. 164-167. w języku niemieckim: Industrie 4.0. Zob. K. Schwab Czwarta rewolucja przemysłowa, przeł. A.D. Kamińska, Wydawnictwo Studio EMKA, Warszawa 2018 (K. Schwab The fourth industrial revolution, World Economic Forum, Geneva 2016). 
audiosfery. Ten kontekst okazuje się kluczowy, ponieważ pozwala sformułować główną hipotezę: w warunkach wzmagającej się kakofonii medialnej i, w konsekwencji, postępującej hiperestezji słuchowej zmieniają się nieuchronnie również sposoby podejścia do zjawisk literackich i ich wymiaru dźwiękowego.

\section{6.}

Literatura może być dzisiaj rozpatrywana w świetle koncepcji skryptoralności z uwagi przede wszystkim na jej tryb funkcjonowania w społeczeństwie medialnym, szczególny potencjał absorbowania nieabsorbującym dźwiękiem („literatura” oznacza w takim wypadku zarazem tradycyjny tekst i jego realizacje głosowe, transpozycje intermedialne, transfery medialne z wykorzystaniem zarówno audialnych, jak i audiowizualnych kanałów dystrybucji itd.) oraz wiążącą się z tym specyfikę odbioru - czytanie i słuchanie. W praktyce, najogólniej mówiąc, skryptoralność łączy się albo z realną obecnością głosu (realizacje głosowe: w postaci głosu na żywo bądź głosu akuzmatycznego), albo z obecnością jego śladu - odroczoną obecnością - w trakcie lektury, co umożliwia za pośredniczone doświ a d c ze ni e a kuzma ty c z ne. Innymi słowy, w grę wchodzą dwa odmienne tryby przejawiania się głosu, dające się określić jako głos in praesentia oraz głos in absentia. W realiach społeczeństwa medialnego przypadek pierwszy związany bezpośrednio z tradycyjnie rozumianą oralnością i oralnością (z) mediatyzowaną - okazuje się ważny z oczywistych powodów, drugi natomiast - znany od czasów pojawienia się pisma i druku, prowokujący pytania w rodzaju: „Czym jest «głos», skoro to obiekt właśnie bez głosu, cichy obiekt, tekst, z którego tylko czytanie może uczynić przedmiot estetyczny?"49 - wydaje się zwłaszcza na etapie wstępnego rozpoznania mało istotny. Staje się on jednak równie ważny jak pierwszy ze względu na procesy mediatyzacji występujące w tego typu społeczeństwie, to znaczy ze względu na warunki lektury determinowane przez znajomość autorskiej realizacji głosowej i samą pamięć głosu danego autora (do tej złożonej kwestii trzeba będzie jeszcze zaraz powrócić).

Objaśnianie propozycji skryptoralności może ułatwić, jak zakładam, odwołanie się do dwóch różnych w założeniach, aczkolwiek dających się traktować komplementarnie ujęć. Mam na myśli dwie koncepcje literaturoznawców

49 M. Bal Voix/voie narrative: la voix métaphorée, „Cahiers de Narratologie” 2001 no. 10, s. 9. 
amerykańskich: „s ł y s z e n i e gło s ó w”,50 , które Charles Bernstein przybliża w artykule Hearing voices (2009), oraz „c zy ta n i e gło s ó w”, wyłożone przez Garretta Stewarta w książce Reading voices: literature and the phonotext $(1990)^{52}$. Bez wątpienia jedna i druga propozycja literaturoznawcza odnosi się do czytania i słyszenia/słuchania. W rzeczywistości idzie o podwójny paradoks ujawniający skomplikowany status literatury i specyficzny tryb działania odbiorcy: z jednej strony słuchanie w jakiejś mierze zastępujące czy też eliminujące praktyki czytania (to kwestia „,audiotekstu" Bernsteina), z drugiej - czytanie prowokujące słyszenie w wyobraźni (to kwestia „fonotekstu" Stewarta, analizowana między innymi na przykładzie utworów Jamesa Joyce'a' ${ }^{53}$ ), a ściślej tego rodzaju czytanie, które prowadzi do wyobraźniowej rekonstrukcji głosu/głosów czy środowiska dźwiękowego. Pierwsza z tych praktyk jest ewidentnym rezultatem bycia w kulturze audialnej, druga z kolei okazuje się zarazem rezultatem przyjęcia określonych założeń interpretacyjnych i stanowi kontynuację niegdysiejszych sposobów postrzegania literackiej „reprodukcji” dźwięku, upowszechnionych w czasach przed rozwojem przemysłu fonograficznego i w epokach poprzedzających fazę społeczeństwa medialnego. Dzisiaj obydwie te praktyki, niezależnie od narzucających się w oglądzie różnic i analogii (słuchanie niewykluczające "pamięci tekstu”, czytanie niewykluczające „pamięci głosu/dźwięku”), wiążą się ze słyszeniem/ słuchaniem, z akceptacją perspektywy antropologii dźwięku i z wykorzystaniem podobnych narzędzi pomocnych w konstruowaniu interpretacji, mimo że w drugim wypadku odbiorca, wychodząc od reguł gry, które sankcjonują i uprzywilejowują tradycyjne nurty literaturoznawstwa, musi pokonać okrężną drogę z konieczności odwoływania się do zapośredniczonego doświadczenia akuzmatycznego. Sytuacja literatury staje się więc obecnie nieco inna w porównaniu z tą nakreśloną przez Stewarta (literaturoznawcy

Ch. Bernstein Hearing voices, w: The sound of poetry / The poetry of sound, ed. by M. Perloff, C. Dworkin, The University of Chicago Press, Chicago-London 2009, s. 142-148. ley 1990. Do koncepcji literatury i fonotekstu Garrett Stewart powraca także w późniejszych pracach, zob. G. Stewart The deed of reading: literature, writing, language, philosophy, Cornell University Press, Ithaca, NY-London 2015, passim. Zob. komentarz do propozycji Stewarta: J.St. Clair Literature and sound, w: The Routledge Companion to Sound Studies, ed. by M. Bull, Routledge, London-New York 2019, S. 354.

53 Zob. G. Stewart „An earsighted view”: Joyce's modality of the audible, w: tegoż Reading voices: literature and the phonotext, s. 232-258. 
poprzestającego w zasadzie na kwestii reprezentacji i wyobraźniowym rekonstruowaniu dźwięku), ponieważ dwa wskazane wyżej rodzaje działania, czyli słuchanie zastępujące czytanie oraz czytanie prowokujące słyszenie w wyobraźni, umożliwia i wręcz narzuca rzeczywistość - konkretna audiosfera - społeczeństwa medialnego.

\section{7.}

Literaturę należałoby rozpatrywać jednocześnie jako fen o men pis ma i fenomen głosu (dźwięku) - zwłaszcza w aktualnych warunkach kulturowych, w realiach społeczeństwa, które żywi się obrazem i dźwiękiem, uprzywilejowuje przekaz wizualny i przekaz audialny. W tego typu społeczeństwie, by powtórzyć, zyskuje na znaczeniu rozszerzona technologicznie audiosfera i jej wpływ na percepcję słuchową (w nauce przekłada się to w prostej konsekwencji na szersze zainteresowanie problematyką kultury audialnej i rozwój badań w rodzaju sound studies). Ten stan rzeczywistości, który zawdzięcza się przemieszczonym dźwiękom, obfituje zarówno w ewidentne sytuacje związane ze słyszeniem/słuchaniem (reakcje na media audialne i audiowizualne, muzak, audio branding etc.), jak i mniej ewidentne, czego przykładem jest słuchanie literatury odbywające się w trzech różnych okolicznościach. Odbiór literatury za sprawą percepcji słuchowej umożliwia w społeczeństwie medialnym, po pierwsze, sytuacja bezpośrednia, a zatem słuchanie bezpośrednie ${ }^{54}$ (słuchanie realizacji głosowych na żywo), po drugie - sytuacja akuzmatyczna łącząca się ze słuchaniem pośrednim i dźwiękiem akuzmatycznym (odsłuchiwanie nagrań; obecność głosu in praesentia), po trzecie wreszcie - ze względu na brak fazy realizacji dźwiękowej w aktualnym środowisku - specyficzna sytuacja akuzmatyczna związana z pamięcią głosu w trakcie lektury danego tekstu (rekonstruowanie czy odkrywanie dźwięku typowe, jak powiedziałby David Toop, dla „cichych mediów”55; obecność głosu in absentia). Trzy wyróżnione przypadki, należałoby to raz jeszcze podkreślić, wiążą się w jakiejś mierze ze słuchaniem, przy czym dwa pierwsze - w sposób bezpośredni (możliwość taką dają publiczne odczytania i ich nagrania audialne

54 Ten sposób odbioru literatury nie jest oczywiście niczym nowym, stanowi kontynuację - w nowych wszakże warunkach kulturowych - praktyk istniejących już w pierwotnych kulturach oralnych. 
lub audiowizualne), trzeci natomiast - w sposób pośredni, ponieważ proces lektury i, by rzecz ująć metaforycznie, ,odsłuchiwania tekstu” zachodzi w trybie zapośredniczonego doświadczenia akuzmatycznego (za sprawą pamięci głosu). W kulturze akuzmatycznej, na co chciałbym w tym miejscu zwrócić szczególną uwagę, ważne okazuje się nie tylko słuchanie pośrednie literatury, lecz także to związane z pamięcią słuchową, polegające na uobecnianiu głosu autora w trakcie czytania.

Literatura objaśniana jako ślad głosu (dźwięku) wcale nie jest problemem, który powinien zostać podjęty przy innej okazji, jak może się wydawać w chwili jej sytuowania na tle ewidentnych przypadków słyszenia/słuchania (to znaczy słuchania bezpośredniego lub akuzmatycznego). Uwzględniając zresztą szeroki kontekst historyczny, warto pamiętać, że dźwięk przed erą fonografii nie ma swojego zapisu audialnego, nie ma - jak pismo - swojego "kamienia z Rosetty", nie ma więc i swoich odkrywców pokroju Jean-François'a Champolliona. Przed wynalezieniem urządzeń rejestrujących dźwięk i przed powstaniem przemysłu fonograficznego wszelkie formy materialnego utrwalania świata dźwięków mają charakter wyłącznie "piśmienniczy”. Zachowało się wiele śladów i świadectw tego rodzaju praktyk: w kulturze europejskiej na przykład w różnych okresach ukształtowały się i były wykorzystywane w muzyce rozmaite systemy notacyjne, takie jak notacja diastematyczna (opracowana w X wieku, funkcjonująca najpierw w postaci zapisu bez linii - diastematia in campo aperto), system znany powszechnie jako solmizacja (stworzony przez Gwidona z Arezzo w wieku XI), tabulatura (kilka konwencji stosowanych w okresie od XV do XVII stulecia), zapis partyturowy, doceniany coraz bardziej począwszy od schyłku XVI wieku. Istniały zarazem przez całe stulecia literackie formy „rejestracji” i „reprodukcji” dźwięku (znakomite przykłady odnajduje się m.in. w pisarstwie Marcela Prousta czy Jamesa Joyce'a) tworzone przy wykorzystaniu konwencjonalnego pisma, tj. pisma fonetycznego. Inna przy tym sprawa, że literaturoznawcy przez ostatnie dziesięciolecia nie przywiązywali do tego większej wagi (poza badaczami tradycji oralnych), nie postulowali konieczności analizowania tych form (zarówno literackich reprezentacji audiosfery - prób zapisu dźwiękowego wedle reguł strategii imitacyjnych, tworzonych przy użyciu chociażby onomatopei i ,języka-hałasu", jak i wszelkiego rodzaju literackich deskrypcji kompozycji muzycznych i przejawów tematyzowania muzyki ${ }^{56}$ ), nie przemyśleli również

56 Dobrym przykładem są chociażby wielokrotnie interpretowane „analizy” Prousta, które potrafiły zainteresować tak różnych badaczy, jak Jean-Jacques Nattiez (Proust musicien, Christian 
roli modelowanego w kulturze akuzmatycznej doświadczenia audialnego odbiorcy literatury.

W społeczeństwie medialnym - nie pomijając znaczenia ani tradycyjnych form „reprodukcji” dźwięku w literaturze, ani tym bardziej utworów literackich funkcjonujących w postaci przekazów audialnych - chodzi jednocześnie o jeszcze inny mechanizm, gdy zakłada się, że zapis tekstowy daje się interpretować w kontekście dźwięku, w tym głosu, a nawet pozwala traktować w kategoriach swoistej translacji głos u $\mathrm{u}^{57}$. Ta nowa możliwość interpretacyjna wiąże się bowiem z wcześniejszym (wy)słuchaniem realizacji dźwiękowej (głosowej), z poznanym już uprzednio głosem danego autora, głosem utrwalonym i rezonującym w pamięci czytelnika. I jest to rezultat nie tyle arbitralnego wyboru (dokonywanego przygodnie przez jakiegoś interpretatora w mniejszym lub większym stopniu uwrażliwionego na zjawiska dźwiękowe), ile poniekąd wręcz niemożności wyzwolenia się od działania pamięci: utwór Wisławy Szymborskiej Fotografia z 11 września ${ }^{58}$, poetycki komentarz do tragicznych wydarzeń amerykańskich z 2001 roku - po wysłuchaniu autorskiej realizacji głosowej (w wersji audialnej czy audiowizualnej, radiowej czy telewizyjnej) - trudno czytać nawet po upływie wielu lat „od nowa", bez śladu wcześniejszych doświadczeń audialnych (audiowizualnych), abstrahując od głosu poetki; podobnie jak Tryptyk rzymski ${ }^{59}$ - bez stałej obecności głosu Jana Pawła II. Kwestia pamięci głosu okazuje się jeszcze bardziej skomplikowana w przypadku realiów społeczeństwa medialnego ze względu na to, że nie tylko wiąże się z indywidualną znajomością autorskich realizacji głosowych (m.in. nagrań nierzadko dołączanych do tradycyjnych edycji, by przywołać przykład Wierszy przeczytanych ${ }^{60}$ Tadeusza Różewicza, czy nagrań deponowanych w literackich fonotekach i archiwach dźwiękowych), lecz ma też bezpośredni związek z działalnością twórcy w sferze publicznej, jego aktywnością w mediach, ze sposobami kształtowania i eksponowania własnego wizerunku medialnego (w takiej perspektywie warto przyjrzeć się bliżej wielu

Bourgois, Paris 1984) czy Sam Halliday (Sonic modernity: representing sound in literature, culture and the arts, Edinburgh University Press, Edinburgh 2013, s. 31 i n.).

57 Ten argument wybrzmiewa także w sytuacji twierdzenia, że głos jako artykulacja ciała warunkuje to, co zapisane. Zob. M. Dolar Preface. Is there a voice in the text?, w: Sound effects: the object voice in fiction, ed. by J. Sacido-Romero, S. Mieszkowski, Brill, Rodopi, Leiden-Boston 2015, s. xi.

W. Szymborska Fotografia z 11 września, w: tejże Chwila, Znak, Kraków 2002, s. 35. 
dzisiejszym pisarzom i ich utworom). Być może pisanie „niszczy wszelki głos, wszelkie źródło i wszelki początek"61, jak stwierdzał w 1968 roku Roland Barthes (notabene autor tekstu Écoute ${ }^{62}$, w którym stara się objaśnić precyzyjnie różnicę między słyszeniem a słuchaniem), chociaż można się pokusić również o sformułowanie tezy, że czytanie w dobie mediatyzacji kultury współczesnej stanowi zarazem moment uobecniania głosu w niekończącym się procesie jego „odzyskiwania”, że interpretacja literaturoznawcza - niezależnie od jej głównego zamierzonego celu - pozwala także ocalić to, od czego wychodzi pismo jako translacja głosu.

61 R. Barthes Śmierć autora, przeł. M.P. Markowski, "Teksty Drugie” 1999 nr 1/2, s. 247. Zob. R. Barthes La mort de l'auteur, "Mantéia" 1968 nr 5, s. 12 (zob. także w: tegoż Le bruissement de la langue, Seuil, Paris 1984, s. 61).

62 R. Barthes Écoute [współautor: R. Havas], w: tegoż L'obvie et l'obtus. Essais critiques III, Collection Points Essais, Éditions du Seuil, Paris 1992, s. 217-230. 


\section{Abstract}

\section{Andrzej Hejmej}

JAGIELLONIAN UNIVERSITY (CRACOW)

Listening to Literature in Media Society

Hejmej explores the question of "listening to literature" in the context of cultural developments that shape the modern audiosphere as well as practices of listening/ hearing in media society. He analyses the effects of the expansiveness of sound (cacophony of media, so-called background noise) and the conditioning of aural perception (acousmatic experience, aural hyperaesthesia) as well as the effects of existing within sound as observed in the case of literature. The modern audio experience allows Hejmej to formulate a main thesis: in the realities of media society literature ought to be understood in terms of sciptorality as a phenomenon of writing and at the same time as a phenomenon of voice (sound). Here, scriptorality relates to both the real presence of voice (vocal realisations in the form of live or acousmatic voice) and to the presence of its trace in the process of reading (mediated acousmatic experience). This take on literature eventually leads Hejmej to revise traditional literary scholarship.

\section{Keywords}

literature, listening, hearing, aural hyperaesthesia, voice, script 